\title{
Eosinofil øsofagitt
}

\author{
Sammendrag \\ Bakgrunn. Eosinofil øsofagitt er en \\ kronisk inflammasjonstilstand i spise- \\ røret. De siste årene er man blitt mer \\ oppmerksom på denne sykdommen \\ som en vanlig årsak til dysfunksjon av \\ oesophagus hos både barn og voksne.
}

Materiale og metode. Oversikten bygger på søk i PubMed, gjennomgang av referanselister og forfatternes erfaring med voksne og barn med eosinofil øsofagitt.

Resultater. Eosinofil øsofagitt diagnostiseres stadig oftere i vestlige land, med en prevalens på om lag 50 per 100000 personer. Menn rammes tre ganger så hyppig som kvinner. Sykdommen kan debutere i alle aldre, men hyppigst hos barn og unge voksne. Hos barn er spiseproblemer, magesmerter, kvalme og dårlig vekst vanlige symptomer. Dysfagi og fastsittende mat i spiserøret dominerer hos ungdom og voksne. Hos mange er trolig mekanismen en allergisk reaksjon i spiserøret overfor enkelte matvarer, og over halvparten av pasientene har en atopisk disposisjon. Diagnosen er basert på klinikk, typiske endoskopiske funn og funn av eosinofile granulocytter i spiserørsslimhinnen. Behandlingsmulighetene omfatter diettrestriksjoner, lokalt virkende kortikosteroider og endoskopisk dilatasjon. Dette gir symptomatisk bedring hos de aller fleste.

Fortolkning. Eosinofil øsofagitt diagnostiseres hos stadig flere, men det er usikkert om dette skyldes økt forekomst eller økt oppmerksomhet fra det medisinske miljøet. Kunnskap om sykdommen er viktig, da enkel endoskopisk eller medisinsk behandling gir et godt resultat hos flertallet av pasientene og kan forhindre komplikasjoner som strikturdanning og fastsittende mat i spiserøret.

\section{Øyvind Holme}

oyvind.holme@sshf.no

Medisinsk avdeling

Sørlandet sykehus Kristiansand

og

Det medisinske fakultet

Universitetet i Oslo

\section{Erling Tjora}

Barneklinikken

Haukeland universitetssykehus og

Senter for diabetesgenetikk

Institutt for klinisk medisin

Universitetet i Bergen

\section{Lars Aabakken}

Seksjon for fordøyelsessykdommer

Klinikk for spesialisert medisin og kirurgi

Oslo universitetssykehus, Rikshospitalet

Dysfagi er vanskeligheter med å svelge mat eller drikke og er en ubehagelig følelse. At mat regelrett setter seg fast i spiserøret, oppleves som dramatisk. Pasienten klarer ikke svelge sitt eget spytt, og tilstanden er en øyeblikkelig hjelp-situasjon der endoskopisk fjerning av fremmedlegemet kan bli nødvendig. Refluksassosiert striktur og Schatzkis ring er vanlige benigne årsaker til problemet.

De siste ti årene er man imidlertid blitt mer og mer oppmerksom på eosinofil øsofagitt som en hyppig forklaring på både dysfagi og fastsittende mat i spiserøret. Eosinofil øsofagitt er karakterisert ved kronisk inflammasjon og infiltrasjon av eosinofile granulocytter i spiserørsslimhinnen og har sammenheng med allergi mot fødemidler. Sykdommen er imidlertid lite kjent, og mange av pasientene har vært til gjentatte gastroskopier og har hatt plager i mange år før riktig diagnose blir stilt $(1,2)$. Eosinofil gastroenteritt er nylig blitt omtalt i Tidsskriftet (3), men de to tilstandene er distinkt forskjellige sykdommer. I denne artikkelen gis en oversikt over eosinofil øsofagitt, med vekt på diagnostikk og behandling.

\section{Materiale og metode}

Artikkelen er basert på søk i PubMed på $\mathrm{MeSH}$-termene «eosinophilic esophagitis», «eosinophilia» og «esophagitis» i tillegg til tekstordene «eosinophil*» og «esophag*» og manuell gjennomgang av referanselistene til relevante oversiktsartikler, i tillegg til forfatternes erfaring med diagnostikk og behandling av voksne og barn med eosinofil øsofagitt. Søket ble sist oppdatert i juli 2011.

\section{Definisjon}

Eosinofil øsofagitt er en kronisk, immunmediert/antigenmediert spiserørssykdom karakterisert klinisk ved symptomer relatert til dysfunksjon av spiserøret og histologisk ved inflammasjon med eosinofile granulocytter i spiserørsslimhinnen (4). Både de kliniske og de patologiske kriteriene må være oppfylt før diagnosen kan stilles.

\section{Epidemiologi}

Eosinofil øsofagitt ble først beskrevet i 1978 (5) og er rapportert fra alle kontinenter, unntatt Afrika (6). Lidelsen diagnostiseres i alle aldre, med høyest forekomst i 20-30-årsalderen. Av ukjente årsaker er eosinofil øsofagitt tre ganger så hyppig hos menn som hos kvinner (7). En forhistorie med atopiske sykdommer som astma, atopisk dermatitt eller allergisk rhinokonjunktivitt finnes hos $50-70 \%$ av pasientene $(8-10)$. I flere studier er det rapportert om økende prevalens av eosinofil øsofagitt $\mathrm{i}$ vestlige land $(2,11$, 12), og prevalenstallene nærmer seg tallene for andre inflammatoriske gastrointestinale tilstander som Crohns sykdom og ulcerøs kolitt $(6,13)$. Det er imidlertid usikkert om dette dreier seg reell insidensøkning i befolkningen eller bare er et resultat av økt oppmerksomhet om tilstanden fra medisinske miljøer.

\section{Patogenese}

Eosinofil øsofagitt er best undersøkt hos barn. Både mat- og inhalasjonsallergener synes å spille en rolle i patogenesen (13). De første indikasjonene på at sykdommen kunne skyldes matvarer, kom med studier som viste at de fleste barn med eosinofil øsofagitt ble kvitt sine plager når de ble behandlet med elemental diett, et utelukkende aminosyrebasert regime uten allergene egenskaper (14-16). Dietten førte til histologisk normalisering i oesophagus hos de fleste av

\section{Hovedbudskap}

- Eosinofil øsofagitt er en kronisk inflammasjonstilstand i spiserøret som skyldes reaksjon på matallergener

- Sykdommen gir dysfagi og er en vanlig årsak til fastsittende mat i spiserøret

- Sykdommen kan debutere i alle aldre, men bør særlig mistenkes hos unge menn med atopi i sykehistorien 
barna. Reintroduksjon av spesifikke matvarer ga residiv av plagene. Positive hudreaksjoner på prikk- og lappetester mot matallergener indikerer at det kan dreie seg om en blanding av både IgE-medierte og ikke-IgEmedierte allergiske reaksjoner (14).

Betydningen av inhalasjonsallergener er mer kontroversiell. Så mange som 71-93 \% av pasientene tester positivt mot luftveisallergener med spesifikk IgE eller prikktester på hud, men det er uklart hvilken rolle dette har i patogenesen $(4,17,18)$. Imidlertid har man observert en sesongvariasjon $i$ antall nyoppdagede tilfeller av eosinofil øsofagitt. Færre tilfeller diagnostiseres på vinteren når forekomsten av inhalasjonsallergener er lav (19). Forverring av dysfagi i pollensesongen er også beskrevet $(10,20)$.

Man antar at inflammasjonskaskaden starter med binding av et allergen til mastceller og antigenpresenterende celler i oesophagusslimhinnen. Mastceller og aktiverte T-celler skiller ut de proinflammatoriske cytokinene interleukin $-4,-5$ og -13 , som virker kjemotaktisk og aktiverende på eosinofile granulocytter. Via migrasjon og diapedese invaderer de eosinofile granulocyttene oesophagusslimhinnen, der de kan degranulere og frigjøre ytterligere betennelsesmediatorer som forsterker inflammasjonsprosessen (21). Dette fører til fortykkelse av spiserørsveggen og subepitelial fibrose, med påfølgende dysfunksjon av spiserøret $(22,23)$. Noen studier indikerer en sannsynlig genetisk disposisjon for eosinofil øsofagitt (24). I en studie med 103 personer med sykdommen var for eksempel forekomsten av eosinofil øsofagitt blant førstegradsslektninger 6,8\% (6). Det er også beskrevet en mulig assosiasjon med cøliaki (25).

\section{Symptomer}

Symptomene på eosinofil øsofagitt er aldersavhengige. Hos voksne rapporterer over $90 \%$ om dysfagi for fast føde, enten intermitterende eller kronisk persisterende, og opptil $60 \%$ møter helsevesenet første gang med fastsittende mat i spiserøret (26). Om lag en femdel av de voksne har samtidig halsbrann (27). Hos barn er den kliniske presentasjonen annerledes. De minste barna har oftest symptomer som kan minne om gastroøsofageal refluks - spisevegring og dårlig vekst i småbarnsalderen og etter hvert gulping, oppkast og magesmerter. Hos de eldste barna likner symptomene dem man ser hos voksne (10).

\section{Funn}

De fleste pasientene har kjent atopisk konstitusjon. Det er derfor ikke overraskende at $50-60 \%$ har økt antall eosinofile granulocytter og forhøyet total $\operatorname{IgE}$ i perifert blod (28-31).

\section{Endoskopi}

De makroskopiske funn i spiserøret kan variere. Typisk kan man se langsgående furer (fig 1) og intermitterende konsentriske ringer («feline esophagus») (fig 2) (9). Hvitlige plakk i slimhinnen representerer eosinofile mikroabscesser. Man kan finne både korte strikturer og smalkalibret oesophagus over et lengre område. Slimhinnen er ofte svært fragil, og store rifter kan oppstå ved passasje med gastroskopet (fig 3). Biopsier bør tas fra spiserøret $\mathrm{i}$ både distale og midtre del og sendes til mikroskopisk undersøkelse på separate glass.

Gastroøsofageal reflukssykdom gir også $ø \mathrm{kt}$ antall eosinofile granulocytter i slimhinnen, men dette er mest uttalt distalt, der syrepåvirkningen er størst. Økt antall eosinofile granulocytter i både proksimale og distale biopsier taler for at det er eosinofil øsofagitt (32). Da eosinofil infiltrasjon kan opptre flekkevis i spiserørsslimhinnen, er det anbefalt at det tas minst fem biopsier (33). Ved mistenkt eosinofil øsofagitt er det viktig å ta vevsprøver selv om man ikke ser noe galt makroskopisk, da slimhinnen kan se normal ut i opptil $30 \%$ av tilfellene (9). Hos barn tas det rutinemessig i tillegg biopsier fra ventrikkel og duodenum ved øvre endoskopi.

\section{Histologi}

Det kreves at minst én av biopsiene fra oesophagus inneholder $\geq 15$ eosinofile granulocytter per synsfelt ved 400 ganger forstørrelse i lysmikroskopet (4). Andre typiske histologiske tegn er degranulerte eosinofile granulocytter og overflatiske eosinofile mikroabscesser, definert som en ansamling av mer enn fire eosinofile granulocytter. Det basale laget av plateepitellaget kan være hyperplastisk og utgjøre mer enn $50 \%$ av tykkelsen (34). Subepitelial fibrose kan ses ved dype biopsier (22).

Ingen av de histologiske tegn er patognomoniske for eosinofil øsofagitt, og de må sammenholdes med kliniske funn. En rekke andre lidelser kan også gi eosinofili i spiserørsslimhinnen og må utelukkes, som gastroøsofageal reflukssykdom, Crohns sykdom og systemiske vaskulitter (4).

\section{Andre undersøkelser}

Gastroøsofageal reflukssykdom er den viktigste differensialdiagnosen til eosinofil øsofagitt. Refluks gir vanligvis ikke mer enn fem eosinofile granulocytter per synsfelt, men langt høyere tall er beskrevet (35). Hos barn er de kliniske tegn ved disse to tilstandene vanskelig å skille, derfor gjennomfører vi alltid 24-timers $\mathrm{pH}$-registrering i spiserøret hos dem. Hos voksne gjør vi dette der det er tvil om diagnosen.

Manometrisk undersøkelse av spiserøret er normal hos over halvparten av pasientene og er av liten diagnostisk verdi (36), bortsett fra i differensialdiagnostisk utredning av dysfagi. Endoskopisk ultralyd kan påvise fortykkede vegglag i oesophagus (23), men har ingen plass i vanlig klinisk utredning av tilstanden.

\section{Allergologisk utredning}

Da opptil $70 \%$ av både barn og voksne med eosinofil øsofagitt har andre atopiske lidel-

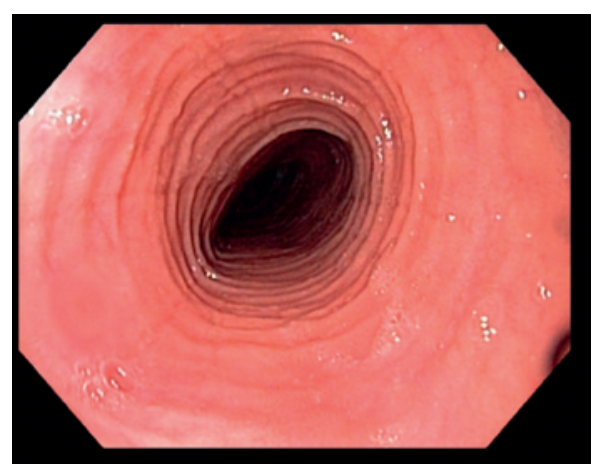

Figur 1 Typiske langsgående furer i spiserøret. 9,8 mm skop kunne ikke passere initialt. Bildene er gjengitt med tillatelse av Vemund Paulsen, Oslo universitetssykehus, Rikshospitalet

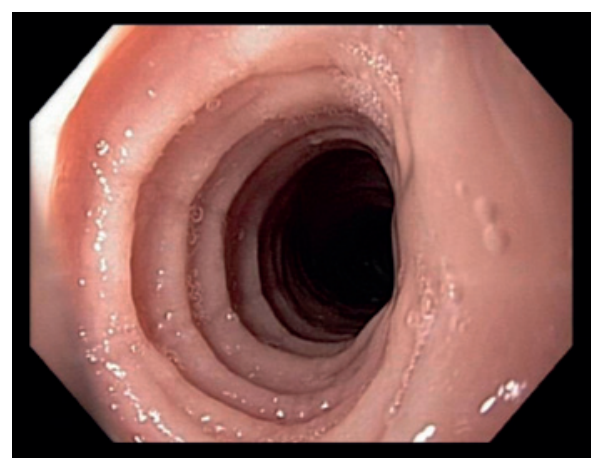

Figur 2 Konsentriske ringer i spiserøret ved endoskopi

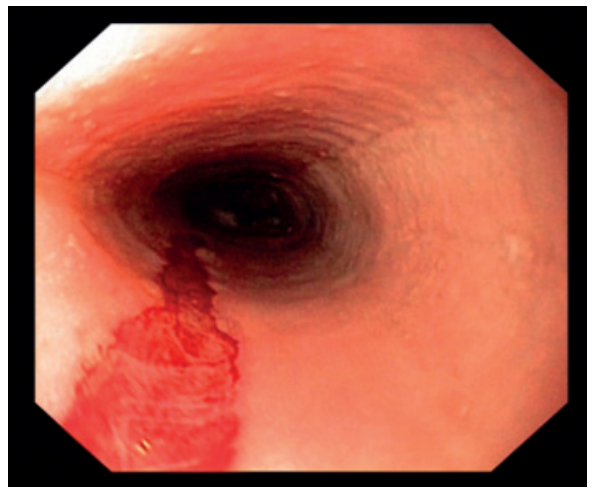

Figur 3 Rift i spiserøret etter passasje med 9,8 mm skop. Samme pasient som på figur 1

ser, som astma, atopisk eksem og allergisk rhinokonjunktivitt, er det ofte indisert å gjøre en generell allergiutredning $(10,30)$. Vi foretar dette hos alle barn, men ikke rutinemessig hos voksne, da nytten i denne gruppen er dårlig dokumentert. Hos barn omfatter utredningen anamnese og bestemmelse av total IgE og spesifikk IgE samt prikktester mot mat- og inhalasjonsallergener. Utenom tilfeller av straksallergiske reaksjoner, som anafylaksi eller urticaria, gir anamnesen ikke holdepunkter for å avgjøre hvilke matvarer den enkelte pasient reagerer på (17). Dessuten har flere studier vist at pasientene ofte er sensitivisert mot multiple matvarer $(9,14,17)$ identifisert med prikkog lappetester.

Det har imidlertid vist seg at testenes evne 
til å identifisere enkeltmatvarer som årsak til eosinofil øsofagitt varierer. Positiv og negativ prediktiv verdi for prikktester varier fra $33 \%$ til $95 \%$ for ulike matsorter, for lappetester henholdsvis fra $47 \%$ til $94 \%$ (10). Lappetester brukt $i$ allergiutredning av matvarer er for øvrig ikke standardisert og må anses som eksperimentelt (37). Den kliniske nytten av matvareallergiutredning med spesifikk IgE, prikk- og lappetester er uklar (4). Sensitivisering mot en matvare påvist ved positive allergitester er ikke ensbetydende med klinisk allergi.

Vi bruker svarene på allergitestene som utgangspunkt for å diskutere eventuell eliminasjonsdiett med motiverte pasienter og familier. Spesifikk IgE og prikktester mot luftveisallergener viser også sensitivisering hos en stor andel av barn og voksne med eosinofil øsofagitt, men de kliniske konsekvensene av dette er ikke kartlagt $(17,30)$.

\section{Behandling}

Behandlingen av pasienter med eosinofil øsofagitt innebærer en del utfordringer. Blant annet er sykdommens naturlige forløp ikke kjent i detalj, det foreligger ingen klare anbefalinger om oppfølging og behandlingsmålet er ikke definert. Informasjon om spisevaner er uansett viktig. Maten må tygges godt, og pasientene må ta seg god tid ved måltidene. Mange opplever dysfagisymptomene kun i stuasjoner der de må «kaste i seg» maten.

\section{Diett}

Det har vist seg vanskelig å identifisere enkeltmatvarene som forårsaker eosinofil øsofagitt. Empirisk diett hos barn der vanlige allergene matvarer som melk, egg, hvete, peanøtter, soya og sjømat utelates fra kosten, gir symptomatisk bedring hos om lag $70 \%$ og har vist seg å være like effektivt som eliminasjonsdiett basert på hudtester og måling av spesifikk $\operatorname{IgE}(4,14,38)$. Elemental diett er sannsynligvis mer effektivt, men den smakløse løsningen tolereres dårlig og må i praksis ofte tilføres via sonde (13).

Vår erfaring er at symptomenes alvorlighetsgrad sjelden rettferdiggjør en veldig restriktiv diett. Familiene er ofte heller ikke motivert for dette. Eventuell diettbehandling hos barn må gjøres i nært samarbeid med klinisk ernæringsfysiolog for at man skal unngå feilernæring og sikre stort nok kaloriinntak. Hos voksne er kostrestriksjon ved eosinofil øsofagitt lite undersøkt.

\section{Syrehemming}

Samtidig reflukssykdom påvist ved 24-timers pH-måling i spiserøret er beskrevet hos $11-38 \%$ av dem med eosinofil øsofagitt, og behandling med protonpumpehemmer er da indisert (39). I tillegg er man de siste årene blitt oppmerksom på en undergruppe pasienter med kliniske og histologiske tegn forenlig med eosinofil øsofagitt, normal 24-timers $\mathrm{pH}$-registrering og komplett histologisk og klinisk remisjon etter behand- ling med protonpumpehemmer (PPI) såkalt PPI-responsiv øsofageal eosinofili (40). Det er også påvist økt følsomhet for syre i spiserøret hos pasienter med eosinofil øsofagitt (41). Temaet er kontroversielt, og det foreligger ikke klare retningslinjer (4). En pragmatisk tilnærming kan være behandlingsforsøk med protonpumpehemmer og evaluering etter 4-8 uker, eventuelt med fornyet endoskopi med biopsi (42).

\section{Kortikosteroider}

Flutikason inhalasjonsaerosol og budesonidløsning til bruk i forstøver er kjente medikamenter i behandlingen av bronkial astma. Begge har vist seg effektive i behandlingen av eosinofil øsofagitt hos barn og voksne. Flutikason sprayes inn i munnen for deretter å svelges, mens budesonid kan mikses med sukralose (Splenda) for at blandingen skal bli mer viskøs. Det er viktig ikke å spise eller drikke den første halvtimen etter medikamentinntak. I randomiserte, placebokontrollerte forsøk har budesonid 1-2 mg daglig ført til histologisk remisjon hos $61-87 \%$ av pasientene $(43,44)$. Behandling med 440 mikrogram flutikason to ganger daglig $\mathrm{i}$ tre måneder ga histologisk remisjon hos $50 \%$ en randomisert, placebokontrollert studie med barn (45). I to observasjonsstudier med voksne ga 220-550 mikrogram flutikason to ganger daglig i seks uker histologisk og symptomatisk bedring hos alle pasientene (46, 47). Bedring med budesonidbehandling etter terapisvikt med flutikason er beskrevet (48). Flutikason og budesonid har aldri vært sammenliknet direkte i prospektive randomiserte forsøk. Behandlingen dekkes ikke over blåreseptforskriften, og refusjon må søkes individuelt hos NAV.

Det er ikke påvist systemiske bivirkninger etter lokalbehandling med kortikosteroider til svelging. Oral candidiasis kan oppstå, og det er derfor viktig at pasientene skyller munnen etter bruk. Hvor langvarig behandlingen bør være, er ikke kjent. Residiv få måneder etter seponering $\mathrm{av}$ behandling er vanlig $(10,49)$, og kronisk medisinering kan være nødvendig (50).

Systemisk behandling med kortikosteroider har vært utprøvd hos barn. I en studie der pasientene ble randomisert til enten peroral prednisolon $1 \mathrm{mg} / \mathrm{kg}$ eller flutikason $220-440$ mikrogram to ganger daglig var det ingen forskjell mellom gruppene når det gjaldt symptombedring eller andel pasienter med histologisk bedring (51).

\section{Annen medikamentell behandling}

En rekke andre medikamenter har vært forsøkt i behandlingen av eosinofil øsofagitt. Leukotrienantagonisten montelukast i høye doser har gitt symptombedring, men ingen endring histologisk (52). Verken natriumkromoglykat (9) eller TNF- $\alpha$-hemmeren infliximab (53) har vist seg effektive. Azatioprin har vært lovende $\mathrm{i}$ enkeltkasuistikker (54). Behandling med antistoff mot interleu- kin-5, mepoluzimab, har fort til mindre symptomer og histologisk bedring (55), men har foreløpig ingen plass i klinisk praksis.

\section{Endoskopisk behandling}

Mange av pasientene debuterer med at maten sitter fast i spiserøret, noe som nødvendiggjør endoskopisk fjerning av fremmedlegemet (26). Disse pasientene skal henvises som øyeblikkelig hjelp til sykehusavdeling der endoskopi med fleksibelt skop er tilgjengelig. Behandling med stivt skop skal unngås. Som regel er den endoskopiske fjerningen av fremmedlegemet enkel og skånsom med lett sedasjon hos voksne. Intubasjonsnarkose er nødvendig hos barn.

Vår erfaring er at den endoskopiske behandlingen av fastsittende mat fører til en ikke ubetydelig dilatasjon i seg selv, noe som kan gi klinisk bedring i lang tid. Endoskopisk dilatasjonsbehandling av pasienter med eosinofil øsofagitt er kommet i miskreditt grunnet tidlige rapporter om komplikasjoner $\mathrm{i}$ forbindelse med prosedyren, inkludert perforasjoner og dype rifter i spiserøret. I en nylig publisert systematisk oversikt over 671 dilatasjonsbehandlinger hos 468 pasienter ble det imidlertid kun påvist én enkelt perforasjon (56). Sannsynligvis indikerer dette at man nå i økende grad er klar over faren ved endoskopisk dilatasjonsbehandling ved eosinofil øsofagitt og bruker utstyr med mindre diameter og eventuelt utfører blokkingen i flere seanser. Hvis man utfører dilatasjonsbehandling, er det viktig å informere pasienten om at mange får smerter etter prosedyren (57). Endoskopisk behandling gir signifikant bedring av dysfagi hos mer enn $90 \%$, men residiv er vanlig (57).

\section{Prognose}

Sykdommens naturlige forløp er ikke kjent i detalj, men tilstanden antas å være kronisk $(9,31)$. Mange pasienter har imidlertid lite plager fra sin sykdom (31). Malignitet eller økt dødelighet er ikke beskrevet. Komplikasjoner til eosinofil øsofagitt er strikturdanning og fastsittende mat i spiserøret. Spontan perforasjon av oesophagus (Boerhaaves syndrom) har vært beskrevet (58).

\section{Konklusjon}

Eosinofil øsofagitt er en kronisk inflammatorisk sykdom i spiserøret. Matallergener spiller en viktig rolle. Behandlingen må individualiseres og diskuteres med pasienten, eventuelt med foreldrene hvis denne er et barn. Det er viktig med informasjon om gode spisevaner, og for noen kan dette være tilstrekkelig. Eliminasjon av visse matvarer kan føre til histologisk og symptomatisk bedring, men identifikasjon av hvilke fødemidler det skal være, kan være utfordrende. En restriktiv diett kan være vanskelig å følge og føre til nedsatt livskvalitet og feilernæring.

Behandling med protonpumpehemmer er indisert ved samtidig reflukssykdom, men kan også forsøkes hos pasienter med normal 
24-timers $\mathrm{pH}$-registrering. Lokalt virkende kortikosteroider er effektiv og trygg behandling hos både barn og voksne. Mye tyder på at denne behandlingen bør være langvarig. Endoskopisk intervensjon med pneumatisk dilatasjon er effektivt, men ikke helt risikofritt, og bør kanskje forbeholdes dem som ikke responderer tilfredsstillende på annen behandling.

Vi takker Vemund Paulsen, Oslo universitetssykehus, Rikshospitalet, for utlån av bilder, og Michael Bretthauer, Kreftregisteret, for verdifulle råd underveis i skriveprosessen.

\section{Øyvind Holme (f. 1970)}

er spesialist i indremedisin og i fordøyelsessykdommer. Han er overlege ved Seksjon for fordøyelsessykdommer, Medisinsk avdeling. Sørlandet sykehus Kristiansand og stipendiat ved Universitetet i Oslo.

Ingen oppgitte interessekonflikter.

\section{Erling Tjora (f. 1972)}

er stipendiat i permisjon fra stillingen som overlege ved Seksjon for gastroenterologi og ernæring ved Barneklinikken ved Haukeland universitetssykehus.

Ingen oppgitte interessekonflikter.

\section{Lars Aabakken (f. 1962)}

er professor dr.med. og seksjonsoverlege ved Gastrolaboratoriet ved Oslo universitetssykehus, Rikshospitalet.

Ingen oppgitte interessekonflikter.

\section{Litteratur}

1. Kerlin P, Jones D, Remedios M et al. Prevalence of eosinophilic esophagitis in adults with food bolus obstruction of the esophagus. J Clin Gastroenterol 2007; 41: 356-61. doi:10.1097/ 01.mcg.0000225590.08825.77

2. Straumann A. Clinical evaluation of the adult who has eosinophilic esophagitis. Immunol Allergy Clin North Am 2009: 29: 11-8, vii. doi:10.1016/ jiac.2008.09.007

3. Qvigstad G, Viset T, Fougner R. Eosinofil gastroenteritt. Tidsskr Nor Legeforen 2011: 131: 353-6. doi:10.4045/tidsskr.10.0594

4. Liacouras CA, Furuta GT, Hirano I et al. Eosinophiic esophagitis: updated consensus recommendations for children and adults. J Allergy Clin Immunol 2011; 128: 3-20 e6.

5. Landres RT, Kuster GG. Strum WB. Eosinophilic esophagitis in a patient with vigorous achalasia. Gastroenterology 1978; 74: 1298-301.

6. Noel RJ, Putnam PE, Rothenberg ME. Eosinophilic esophagitis. N Engl J Med 2004: 351: 940-1. doi:10.1056/NEJM20040826351092

7. Kapel RC, Miller JK, Torres C et al. Eosinophilic esophagitis: a prevalent disease in the United States that affects all age groups. Gastroenterology 2008; 134: 1316-21. doi:10.1053/ gastro.2008.02.016

8. Prasad GA, Alexander JA, Schleck CD et al. Epidemiology of eosinophilic esophagitis over three decades in Olmsted County, Minnesota. Clin Gastroenterol Hepatol 2009; 7: 1055-61. doi:10.1016/j.cgh.2009.06.023

9. Liacouras CA, Spergel JM, Ruchelli E et al. Eosinophilic esophagitis: a 10-year experience in 381 children. Clin Gastroenterol Hepatol 2005; 3 1198-206. doi:10.1016/S1542-3565(05)00885-2

10. Spergel JM, Brown-Whitehorn TF, Beausoleil JL et al. 14 years of eosinophilic esophagitis: clinical features and prognosis. J Pediatr Gastroenterol Nutr 2009; 48: 30-6. doi:10.1097/ MPG.0b013e3181788282

11. Cherian S, Smith NM, Forbes DA. Rapidly increas ing prevalence of eosinophilic oesophagitis in Western Australia. Arch Dis Child 2006; 91: 1000-4. doi:10.1136/adc.2006.100974

12. Whitney-Miller CL, Katzka D, Furth EE. Eosinophilic esophagitis: a retrospective review of esophageal biopsy specimens from 1992 to 2004 at an adult academic medical center. Am J Clin Pathol 2009; 131: 788-92. doi:10.1309/ AJCPOMPXJFP7EB4P

13. Spergel JM. Eosinophilic esophagitis in adults and children: evidence for a food allergy component in many patients. Curr Opin Allergy Clin Immunol 2007; 7: 274-8. doi:10.1097/ ACl.0b013e32813aee4a

14. Spergel JM, Andrews T, Brown-Whitehorn TF et al. Treatment of eosinophilic esophagitis with specific food elimination diet directed by a combination of skin prick and patch tests. Ann Allergy Asthma Immunol 2005; 95: 336-43. doi:10.1016/ S1081-1206(10)61151-9

15. Kelly KJ, Lazenby AJ, Rowe PC et al. Eosinophilic esophagitis attributed to gastroesophageal reflux: improvement with an amino acid-based formula. Gastroenterology 1995; 109: 1503-12. doi:10.1016/0016-5085(95)90637-1

16. Markowitz JE, Spergel JM, Ruchelli E et al. Elemental diet is an effective treatment for osinophilic esophagitis in children and adolescents. Am J Gastroenterol 2003: 98: 777-82. doi:10.1111/j.1572-0241.2003.07390.x

17. Erwin EA, James HR, Gutekunst HM et al. Serum IgE measurement and detection of food allergy in pediatric patients with eosinophilic esophagitis. Ann Allergy Asthma Immunol 2010; 104: 496-502. doi:10.1016/j.anai.2010.03.018

18. Penfield JD, Lang DM, Goldblum JR et al. The role of allergy evaluation in adults with eosinophilic esophagitis. J Clin Gastroenterol 2010: 44: 22-7. doi:10.1097/MCG.0b013e3181a1bee5

19. Wang FY, Gupta SK, Fitzgerald JF. Is there a seasonal variation in the incidence or intensity of allergic eosinophilic esophagitis in newly diagnosed children? J Clin Gastroenterol 2007: 41: 451-3. doi:10.1097/01.mcg.0000248019.16139.67

20. Fogg MI, Ruchelli E, Spergel JM. Pollen and eosinophilic esophagitis. J Allergy Clin Immunol 2003: 112: 796-7 doi:10.1016/ 50091-6749(03)01715-9

21. Moawad FJ, Veerappan GR, Wong RK. Eosinophilic esophagitis. Dig Dis Sci 2009; 54: 1818-28. doi:10.1007/s10620-009-0873-6

22. Chehade M, Sampson HA, Morotti RA et al. Esophageal subepithelial fibrosis in children with eosinophilic esophagitis. J Pediatr Gastroenterol Nutr 2007; 45: 319-28. doi:10.1097/ MPG.0b013e31806ab384

23. Fox VL, Nurko S, Teitelbaum JE et al. High-resolution EUS in children with eosinophilic «allergic» esophagitis. Gastrointest Endosc 2003; 57: 30-6. doi:10.1067/mge.2003.33

24. Collins MH, Blanchard C, Abonia JP et al. Clinical, pathologic, and molecular characterization of familial eosinophilic esophagitis compared with sporadic cases. Clin Gastroenterol Hepatol 2008; 6: 621-9. doi:10.1016/j.cgh.2008.01.004

25. Leslie C. Mews C, Charles A et al. Celiac disease and eosinophilic esophagitis: a true association. J Pediatr Gastroenterol Nutr 2010; 50: 397-9.

26. Sgouros SN, Bergele C, Mantides A. Eosinophilic esophagitis in adults: a systematic review. Eur J Gastroenterol Hepatol 2006; 18: $211-7$. doi:10.1097/00042737-200602000-00015

27. Katzka DA. Demographic data and symptoms of eosinophilic esophagitis in adults. Gastrointest Endosc Clin N Am 2008; 18: 25-32, viii. doi:10.1016/j.giec.2007.09.005

28. Aceves SS, Newbury RO, Dohil R et al. Esophagea remodeling in pediatric eosinophilic esophagitis. J Allergy Clin Immunol 2007; 119: 206-12. doi:10.1016/j.jaci.2006.10.016

29. Erwin EA, James HR, Gutekunst HM et al. Serum IgE measurement and detection of food allergy in pediatric patients with eosinophilic esophagitis. Ann Allergy Asthma Immunol 2010; 104: 496-502. doi:10.1016/j.anai.2010.03.018

30. Roy-Ghanta S, Larosa DF, Katzka DA. Atopic characteristics of adult patients with eosinophilic esophagitis. Clin Gastroenterol Hepatol 2008; 6 : 531-5. doi:10.1016/j.cgh.2007.12.045

31. Straumann A, Spichtin HP, Grize L et al. Natural history of primary eosinophilic esophagitis: a follow-up of 30 adult patients for up to 11.5 years. Gastroenterology 2003; 125: 1660-9. doi:10.1053/ j.gastro.2003.09.024

32. Lee S, de Boer WB, Naran A et al. More than just counting eosinophils: proximal oesophageal involvement and subepithelial sclerosis are majo diagnostic criteria for eosinophilic oesophagitis J Clin Pathol 2010; 63: 644-7. doi:10.1136/ jcp.2010.078402

33. Gonsalves N, Policarpio-Nicolas M, Zhang Q et al. Histopathologic variability and endoscopic correlates in adults with eosinophilic esophagitis. Gastro intest Endosc 2006; 64: 313-9. doi:10.1016/ j.gie.2006.04.037

34. Genevay M, Rubbia-Brandt L, Rougemont AL. Do eosinophil numbers differentiate eosinophilic esophagitis from gastroesophageal reflux disease? Arch Pathol Lab Med 2010; 134: 815-25.

35. Ngo P. Furuta GT, Antonioli DA et al. Eosinophils in the esophagus-peptic or allergic eosinophilic esophagitis? Case series of three patients with esophageal eosinophilia. Am J Gastroenterol 2006 101: 1666-70. doi:10.1111/j.1572-0241.2006.00562.x

36. Furuta GT, Liacouras CA, Collins MH et al. Eosinophilic esophagitis in children and adults: a systematic review and consensus recommendations for diagnosis and treatment. Gastroenterology 2007: 133: 1342-63. doi:10.1053/ j.gastro.2007.08.017

37. Chehade M, Aceves SS. Food allergy and eosinophilic esophagitis. Curr Opin Allergy Clin Immuno 2010; 10: 231 -7. doi:10.1097/ ACl.0b013e328338cbab

38. Kagalwalla AF, Sentongo TA, Ritz $S$ et al. Effect of six-food elimination diet on clinical and histologic outcomes in eosinophilic esophagitis. Clin Gastro enterol Hepatol 2006; 4: 1097-102. doi:10.1016/ j.cgh.2006.05.026

39. Molina-Infante J, Ferrando-Lamana L, MateosRodríguez JM et al. Overlap of reflux and eosinophilic esophagitis in two patients requiring different therapies: a review of the literature. World J Gastroenterol 2008; 14: 1463-6. doi:10.3748/ wjg.14.1463

40. Molina-Infante J, Hernandez-Alonso M, VinagreRodriguez $\mathrm{G}$ et al. Proton pump inhibitors therapy for esophageal eosinophilia: simply following consensus guidelines. J Gastroenterol 2011; 46: 712-3. doi:10.1007/s00535-011-0388-8

41. Krarup AL, Villadsen GE, Mejlgaard E et al. Acid hypersensitivity in patients with eosinophilic oesophagitis. Scand J Gastroenterol 2010; 45 : 273-81. doi:10.3109/00365520903469931

42. Hirano I. Eosinophilic esophagitis and gastroesophageal reflux disease: there and back again Clin Gastroenterol Hepatol 2011: 9: 99-101. doi:10.1016/j.cgh.2010.11.001

43. Straumann A, Conus S, Degen L et al. Budesonid is effective in adolescent and adult patients with active eosinophilic esophagitis. Gastroenterology 2010; 139: 1526-37.

44. Dohil R, Newbury R, Fox L et al. Oral viscous budesonide is effective in children with eosinophilic esophagitis in a randomized, placebo-controlled trial. Gastroenterology 2010; 139: 418-29. doi:10.1053/j.gastro.2010.05.001

45. Konikoff MR, Noel RJ, Blanchard C et al. A randomized, double-blind, placebo-controlled trial of fluticasone propionate for pediatric eosinophilic esophagitis. Gastroenterology 2006; 131: 1381 -91. doi:10.1053/j.gastro.2006.08.033

46. Arora AS, Perrault J, Smyrk TC. Topical corticosteroid treatment of dysphagia due to eosinophilic esophagitis in adults. Mayo Clin Proc 2003; 78 : $830-5$ doi: $10.4065 / 78.7 .830$

47. Remedios M, Campbell C, Jones DM et al. Eosinophilic esophagitis in adults: clinical, endoscopic, histologic findings, and response to treatment with fluticasone propionate. Gastrointest Endosc 2006: 63: 3-12. doi:10.1016/ j.gie.2005.07.049

48. Krishna SG, Kakati BR, Olden KW et al. Treatment of eosinophilic esophagitis: is oral viscous budesonide superior to swallowed fluticasone spray? Gastroenterol Hepatol (N Y) 2011; 7: 55-9. 
49. Helou EF, Simonson J, Arora AS. 3-yr-follow-up of topical corticosteroid treatment for eosinophilic esophagitis in adults. Am J Gastroenterol 2008; 103 2194-9. doi:10.1111/j.1572-0241.2008.01989.x

50. Straumann A, Conus S, Degen L et al. Long-term budesonide maintenance treatment is partially effective for patients with eosinophilic esophagitis. Clin Gastroenterol Hepatol 2011; 9: 400-9.

51. Schaefer ET, Fitzgerald JF, Molleston JP et al. Comparison of oral prednisone and topical fluticasone in the treatment of eosinophilic esophagitis: a randomized trial in children. Clin Gastroenterol Hepatol 2008; 6: 165-73. doi:10.1016/ j.cgh.2007.11.008

52. Attwood SE, Lewis CJ, Bronder CS et al. Eosinophilic oesophagitis: a novel treatment using Montelukast. Gut 2003; 52: 181-5. doi:10.1136/ gut.52.2.181

53. Straumann A, Bussmann C, Conus S. Infliximab, a monoclonal antibody to TNF-a, for severe eosinophilic esophagitis in adults: a prospective, translational pilot-study. Gastroenterology 2008; 134 (suppl 1): A-105.

54. Netzer P, Gschossmann JM, Straumann A et al, Corticosteroid-dependent eosinophilic oesophagitis: azathioprine and 6 -mercaptopurine can induce and maintain long-term remission. Eur J Gastroenterol Hepatol 2007; 19: 865-9. doi:10.1097/ MEG.0b013e32825abab4

55. Stein ML, Collins MH, Villanueva JM et al. Anti-IL-5 (mepolizumab) therapy for eosinophilic esophagitis. J Allergy Clin Immunol 2006; 118: 1312-9. doi:10.1016/j.jaci.2006.09.007

56. Jacobs JW Jr, Spechler SJ. A systematic review of the risk of perforation during esophageal dilation for patients with eosinophilic esophagitis. Dig Dis Sci 2010; 55: 1512-5. doi:10.1007/ s10620-010-1165-x

57. Schoepfer AM, Gonsalves N, Bussmann C et al. Esophageal dilation in eosinophilic esophagitis: effectiveness, safety, and impact on the underlying inflammation. Am J Gastroenterol 2010; 105: 1062-70. doi:10.1038/ajg.2009.657

58. Riou PJ, Nicholson AG, Pastorino U. Esophageal rupture in a patient with idiopathic eosinophilic esophagitis. Ann Thorac Surg 1996; 62: 1854-6. doi:10.1016/S0003-4975(96)00553-X

Mottatt 13.4. 2011, første revisjon innsendt 19.8. 2011, godkjent 1.9. 2011. Medisinsk redaktør Erlend T. Aasheim. 